\title{
Evident based Case Study and Analysis on Lane - Change Detection
}

\author{
Harleen Kaur \\ Research Scholar \\ Amritsar, India
}

\begin{abstract}
The main goal of this article is to offer various insights in the domain of lane detection system of ITS. More specifically, we provide an overview of various lane detection techniques by establishing several ways of categorization in tabular form. Finally, we spot the left over gaps both in research and in system level evaluation and propose research directions for bridging these gaps. A procedure of lane detection has also been discussed in this paper. Moreover analysis of accidents for last decade has been discussed.
\end{abstract}

\section{Keywords}

ITS, Lane Detection, Accident

\section{INTRODUCTION}

The origin of the formal ITS program dates back to the nineteen sixties with the development of the electronic route guidance system or ERGS in the united states to provide drivers with route guidance information based on real-time traffic analysis .the system used at various intersections across the road network on board 2-way device in vehicles that would form the hub of communication between the driver and the ERGS system and a central computer system that processed the information received from the remote system.Making intelligence within the haul device gets the actual overlap about know-how administering any synergetic improvement in your commuter experience. ITS will provide gains in relation to Decrease patiently waiting time and hardship, Enhance the supply in the device, Increase the safety about customers, Slow up the fuel use together with byproducts, Slow up the detailed expenses, Enhance visitors efficiency, Decrease visitors blockage, Enhance external quality and efficiency, Enhance global financial productions.

Lane detection is an important component of several intelligent vehicle applications, like Lane Keeping Assistance System (LKAS), Lane Departure Warning System (LDWS), lateral control system, Intelligent Cruise Control System (ICCS), Collision Warning system (CWS) and autonomous vehicle guidance systems. Figure 1 represents the lane detection system. Several inhabitants die every year in roadway departure crashes reason being driver inattention. Lane detection techniques are helpful to avoid various accidents as protection is the major reason of these systems. These systems have the aim to identify the lane marks and to inform the driver in case the automobile has a chance to depart from the lane. The difficulty of road or lane detection is a critical task for Advanced Driver Assistance Systems (ADAS). Therefore, it has been an active area of research for the previous two decades with significant progress made in the past few years.
In this paper, a case study of various accidents rate in lane detection has been done. Moreover a survey on various lane detection techniques has also been done which evaluates the features and limitations of the proposed algorithm. Moreover paper has been concluded with future scope to overcome accidents in better manner.

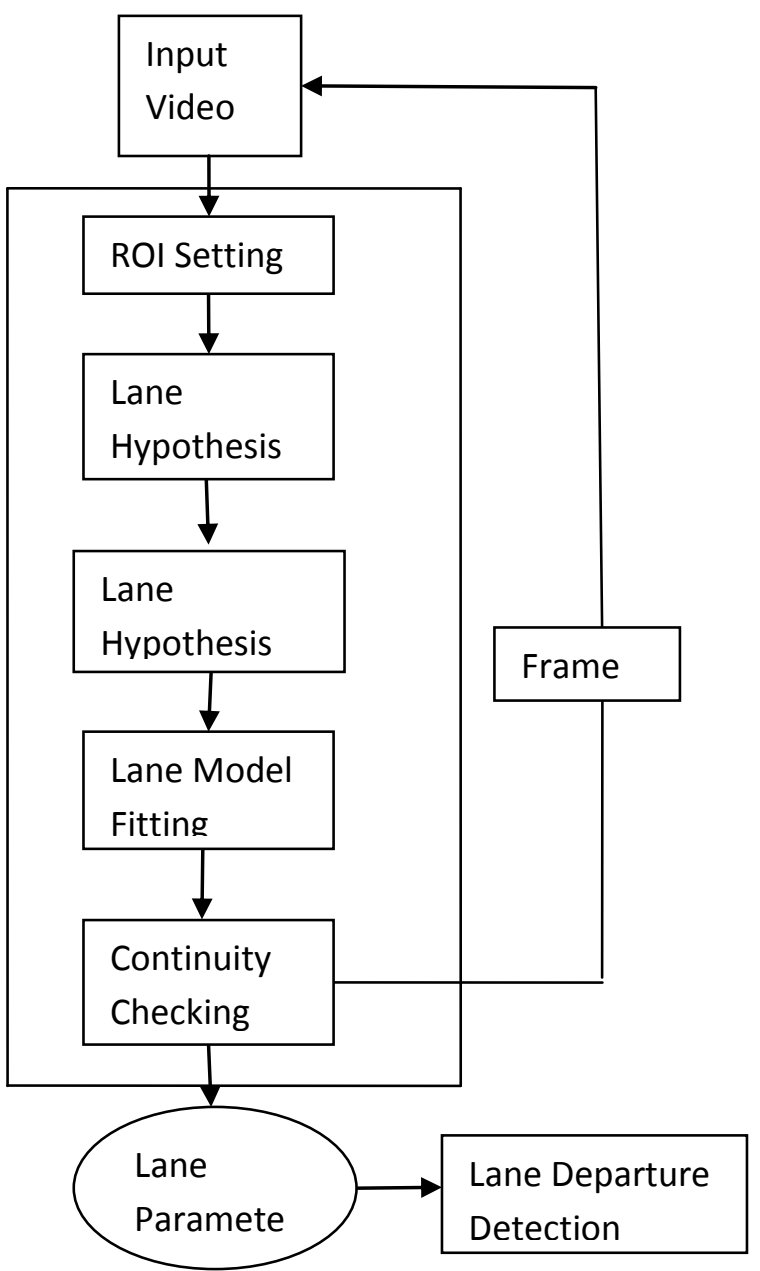

Figure 1: Lane Departure Warning System

\section{RELATED WORK}

Road departure crashes are one of the most frequent and costly collision types in the United States. Estimates are that these road departure collisions are among the top five most frequent crash types and result in the most economic damage of any type of collision. Road departure collisions are more frequent on non-highways in rural areas, with up to $60 \%$ of crashes occurring on 2-lane roads. The presence of center and 
edge lines on paved roads has been found to reduce crash frequency. Aly [18] found that installing markings on roads reduces crash frequency by $21 \%$ on average and $8 \%$ on rural 2-lane roads. More recent studies have found that painted longitudinal markings reduce the crash frequency up to $26 \%$ on rural 2-lane roads .

Malaysia is paying a heavy price due to road accidents, and the cost to the economy last year was about RM9.3bil[1]. Recent statistic shows that the number of fatalities in Malaysia increased to 6,872 deaths in last year. Bukit Aman Internal Security and Public Order Department revealed that the total number of road accidents has increased to 414,421 [2]. In a separate online survey by the community project Malaysians Unite for Road Safety (MUFORS), 61.6\% of the respondents believed that human error like improper vehicle's deviation or unintentional lane change is one of the main causes for road carnages. The U.S. Department of Transportation has reported 42,643 fatalities in the year of 2003, 59\% among which were caused by lane departure. VAMORS technique can be achieved at a high evaluation rate of $25 \mathrm{~Hz}$. This algorithm is best when implemented on PAPRICA system which is capable of processing about 10 frames per second in less than $100 \mathrm{~ms}$. Method using chisquare fitting defines an extended algorithm whose time of calculation is about $0.8 \mathrm{~s}$ for a random search of the best fitting deformable template. The overall time is $2 \mathrm{~s}$. The ALM method can be used for finding the curved road lane which is very much efficient. This method overcame the assumption that the curved lane can be decomposed into a set of line segments. Catmull-Rom spline based lane model simulated by $\mathrm{C}++$, shows robustness in terms of noise present in input image. GOLD system have a capability to work at a rate of $10 \mathrm{~Hz}$ and the whole processing requires five time slots $(100 \mathrm{~ms})$. When the LANA algorithm is compared with spatial feature-based LOIS lane spatial detection algorithm, it resulted that LANA is more efficient. Based on color histograms and Gabor filter, the technique is tested by using $\mathrm{k}$-means clustering to group the 107 sample images for the best color feature set, the best texture feature, and the best color and texture feature. B-Snake algorithm when tested for a $240 * 256$ pixel road image, the whole processing time of CHEVP and lane detection is below 4 s which depends on the number of edge pixels. VIOLET algorithm had standard deviation of error equal to $22.7438 \mathrm{~cm}$ for complex scenarios. RANSAC algorithm detects all lanes in still images of urban streets and works at high rate of $50 \mathrm{~Hz}$. Multiple cues when used, results in time cost of 0.1230s for image size of clip $480 * 360$. Hough Transform with preprocessing have $82 \%$ lane mark detection for left lane and $85 \%$ lane mark detection for right lane. Techniques with IPM and steerable filters achieved detection rate of $90 \%$ for all band widths and any number of scan bands. In a model based technique, where Mahalanobis distance, Gabor filter are used is capable of extracting lane boundaries from a $640 * 480$ image in less than $90 \mathrm{~ms}$. Table 1 shows the analysis of accidents yearly which represents the total number of Accidents, Accidents due to Lane Avoidance and Accidents Avoided due to Lane Detection System and Figure 2 represents the table graphically.
Table 1: Analysis of accidents yearly

\begin{tabular}{|l|l|l|l|}
\hline YEAR & $\begin{array}{l}\text { Total No. Of } \\
\text { Accidents }\end{array}$ & $\begin{array}{l}\text { Accidents due } \\
\text { to Lane } \\
\text { Avoidance }\end{array}$ & $\begin{array}{l}\text { Accidents } \\
\text { Avoided due to } \\
\text { Lane Detection } \\
\text { System }\end{array}$ \\
\hline 2005 & $4,06,736$ & $1,06,855$ & 99,881 \\
\hline 2006 & $4,30,910$ & 80,789 & 50,112 \\
\hline 2007 & $4,40,355$ & 50,356 & 70,887 \\
\hline 2008 & $4,59,930$ & $1,30,383$ & 29,540 \\
\hline 2009 & $4,80,220$ & 40,555 & 30,556 \\
\hline 2010 & $4,85,484$ & $1,80,650$ & 44,833 \\
\hline 2011 & $4,95,630$ & 70,201 & 25,425 \\
\hline 2012 & $4,90,395$ & 90,222 & 40,170 \\
\hline 2013 & $4,86,383$ & 56,235 & 26,145 \\
\hline 2014 & $4,95,476$ & 74,279 & 15,190 \\
\hline
\end{tabular}

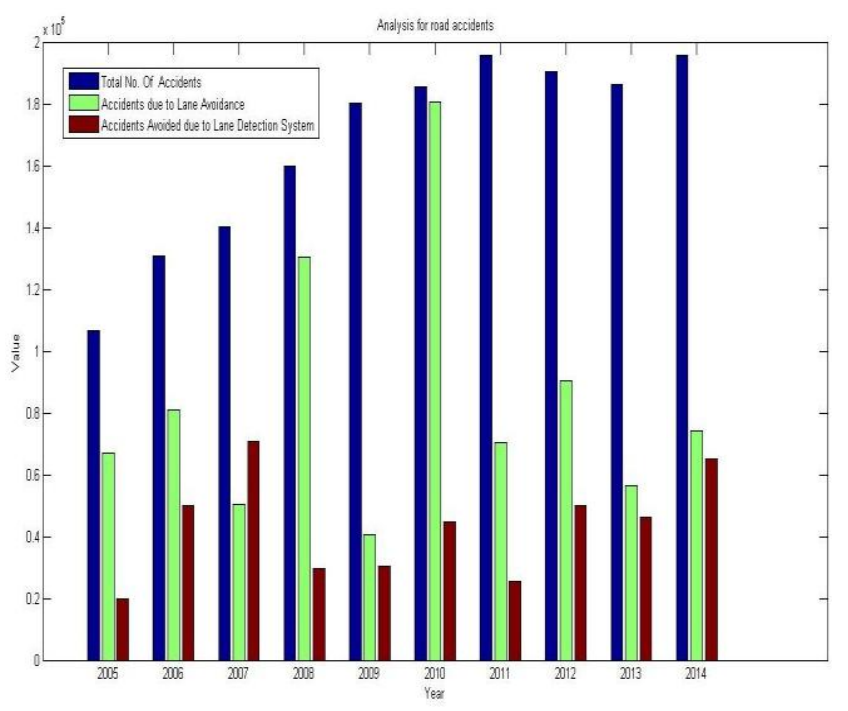

Figure 2: Analysis of data for accidents 


\section{COMPARISON TABLE}

Table 2 shows the comparison of various existing techniques.

\begin{tabular}{|c|c|c|c|c|}
\hline System & Approach & Important Terms & Evaluation & Limitations \\
\hline VAMORs (1992) [3] & $\begin{array}{l}\text { Model- } \\
\text { Based }\end{array}$ & $\begin{array}{l}\text { Clothoid model, } \\
\text { linear } \\
\text { model }\end{array}$ & $\begin{array}{l}\text { Recognizes horizontal and } \\
\text { vertical road curvature } \\
\text { parameters while driving }\end{array}$ & $\begin{array}{l}\text { Limited processing power; road } \\
\text { curvature parameters while } \\
\text { driving }\end{array}$ \\
\hline A. Broggi et al. 1995) [4] & $\begin{array}{l}\text { Feature- } \\
\text { Based }\end{array}$ & DBS, Segmentation & $\begin{array}{l}\text { Fast for real time } \\
\text { constraints; remarkable } \\
\text { performance in terms of } \\
\text { both computational time } \\
\text { and output quality }\end{array}$ & $\begin{array}{l}\text { Presence of obstacle in the } \\
\text { vehicle path creates a problem }\end{array}$ \\
\hline A. Kaske et al. (1995) [5] & $\begin{array}{l}\text { Model- } \\
\text { Based }\end{array}$ & $\begin{array}{l}\text { Chi-square fitting, } \\
\text { Likelihood function }\end{array}$ & $\begin{array}{l}\text { Real time capability; } \\
\text { robust detection against } \\
\text { various environmental } \\
\text { conditions }\end{array}$ & Difficult in implementation \\
\hline Line Snakes (1996) [6] & $\begin{array}{l}\text { Model- } \\
\text { Based }\end{array}$ & $\begin{array}{l}\text { ALM, Hough } \\
\text { Transform }\end{array}$ & $\begin{array}{l}\text { Reduces computational } \\
\text { cost; reliable method for } \\
\text { finding and tracking road }\end{array}$ & $\begin{array}{l}\text { Many false road lanes exist due } \\
\text { to shadows and occlusions by } \\
\text { other passing cars }\end{array}$ \\
\hline GOLD(1998)[7] & $\begin{array}{l}\text { Feature- } \\
\text { Based }\end{array}$ & $\begin{array}{l}\text { Pattern-Matching } \\
\text { technique, } \\
\text { PAPRICA system }\end{array}$ & $\begin{array}{l}\text { Robust with respect to } \\
\text { shadows and changing } \\
\text { illumination conditions, } \\
\text { different road textures and } \\
\text { vehicle movement; } \\
\text { satisfies real time } \\
\text { constraints }\end{array}$ & $\begin{array}{l}\text { When road is unflat or when } \\
\text { road markings are not visible, it } \\
\text { cannot produce valid results; } \\
\text { detection of obstacles } \\
\text { sometimes fails when their } \\
\text { brightness is similar to that of } \\
\text { road }\end{array}$ \\
\hline $\begin{array}{l}\text { Catmull-Rom Spline } \\
\text { (1998) [8] }\end{array}$ & $\begin{array}{l}\text { Model- } \\
\text { Based }\end{array}$ & $\begin{array}{l}\text { Maximum } \\
\text { likelihood }\end{array}$ & $\begin{array}{l}\text { Robust to noise present in } \\
\text { road; describes wider } \\
\text { range of lane structures }\end{array}$ & $\begin{array}{l}\text { Fails when not enough edge } \\
\text { information to build a lane } \\
\text { model }\end{array}$ \\
\hline LANA(1999)[9] & $\begin{array}{l}\text { Model- } \\
\text { Based }\end{array}$ & $\begin{array}{l}\text { DCT, Parabolic } \\
\text { estimation }\end{array}$ & $\begin{array}{l}\text { Detects lane markers well } \\
\text { under a very large and } \\
\text { diverse collection of } \\
\text { roadway images }\end{array}$ & $\begin{array}{l}\text { Limits detection based on } \\
\text { orientation of vehicles }\end{array}$ \\
\hline $\begin{array}{l}\text { Adaptive Fusion (2002) } \\
{[10]}\end{array}$ & $\begin{array}{l}\text { Feature- } \\
\text { Based }\end{array}$ & $\begin{array}{l}\text { Particle Filter, } \\
\text { Bayesian } \\
\text { Probability }\end{array}$ & $\begin{array}{l}\text { In resource constraint, the } \\
\text { system reschedules the } \\
\text { cues to enhance tracking } \\
\text { performance }\end{array}$ & Verification problem \\
\hline C.Rasmussen (2002)[11] & $\begin{array}{l}\text { Region- } \\
\text { Based }\end{array}$ & $\begin{array}{l}\text { Color histograms, } \\
\text { Gabor Filter }\end{array}$ & $\begin{array}{l}\text { Combined cues yield } \\
\text { higher performance than } \\
\text { individual cues }\end{array}$ & Less efficient in sky brightness \\
\hline VIOLET(2004)[12] & $\begin{array}{l}\text { Feature- } \\
\text { Based }\end{array}$ & Steerable Filters & $\begin{array}{l}\text { Robust to complex } \\
\text { shadows, occlusion from } \\
\text { vehicles and varying road } \\
\text { conditions }\end{array}$ & $\begin{array}{l}\text { Obscuring of lane markings by } \\
\text { complex shadows degrades } \\
\text { performance }\end{array}$ \\
\hline C.Rasmussen(2004)[13] & $\begin{array}{l}\text { Region- } \\
\text { Based }\end{array}$ & $\begin{array}{l}\text { Texture orientation, } \\
\text { Gabor wavelet filter }\end{array}$ & $\begin{array}{l}\text { Robust to variety of } \\
\text { straight and curved road } \\
\text { surface materials and } \\
\text { geometrics. }\end{array}$ & $\begin{array}{l}\text { Difficult to identify best cue for } \\
\text { given image }\end{array}$ \\
\hline B-Snake(2004)[14] & $\begin{array}{l}\text { Model- } \\
\text { Based }\end{array}$ & $\begin{array}{l}\text { B-Splines, CHEVP } \\
\text { algorithm, MMSE }\end{array}$ & $\begin{array}{l}\text { Robust against noise; } \\
\text { applicable to both marked } \\
\text { and unmarked roads, } \\
\text { dashed and solid paint line }\end{array}$ & $\begin{array}{l}\text { Cannot detect lanes on basis of } \\
\text { color, texture etc. }\end{array}$ \\
\hline
\end{tabular}




\begin{tabular}{|c|c|c|c|c|}
\hline & & & roads & \\
\hline VIOLET(2006)[15] & $\begin{array}{l}\text { Model- } \\
\text { Based }\end{array}$ & Steerable Filters & $\begin{array}{l}\text { Detect complete vehicle } \\
\text { context including vehicle } \\
\text { surround, state and driver } \\
\text { state }\end{array}$ & Fails in complex shadows \\
\hline Z.W.Kim (2008)[16] & $\begin{array}{l}\text { Feature- } \\
\text { Based }\end{array}$ & $\begin{array}{l}\text { Particle filtering, } \\
\text { RANSAC } \\
\text { Algorithm }\end{array}$ & $\begin{array}{l}\text { Robust in challenging } \\
\text { scenarios }\end{array}$ & Fails in low image quality \\
\hline $\begin{array}{l}\text { J. M. Alvarez et al.( } \\
\text { 2008) [17] }\end{array}$ & $\begin{array}{l}\text { Region- } \\
\text { Based }\end{array}$ & RDI & $\begin{array}{l}\text { Human perception criteria } \\
\text { to improve its usefulness; } \\
\text { suitable for tuning an } \\
\text { individual algorithm }\end{array}$ & Do not optimize a single image \\
\hline M. Aly (2008) [18] & $\begin{array}{l}\text { Model- } \\
\text { Based }\end{array}$ & $\begin{array}{l}\text { RANSAC } \\
\text { algorithm, } \\
\text { splines, IPM }\end{array}$ & $\begin{array}{l}\text { Detects all lanes in still } \\
\text { images }\end{array}$ & $\begin{array}{l}\text { False positives are found when } \\
\text { driving on right lane with no } \\
\text { right lane boundary }\end{array}$ \\
\hline Z. Teng (2010)[19] & $\begin{array}{l}\text { Feature- } \\
\text { Based }\end{array}$ & $\begin{array}{l}\text { Bar filter, HT, } \\
\text { Color Cues, Particle } \\
\text { Filter }\end{array}$ & $\begin{array}{l}\text { Robust detection of lanes } \\
\text { in various situations }\end{array}$ & Fails in dashed lane situations \\
\hline S. Zhou et al.(2010)[20] & $\begin{array}{l}\text { Model- } \\
\text { Based }\end{array}$ & $\begin{array}{l}\text { Geometrical Model, } \\
\text { Gabor Filter, Hough } \\
\text { Transform }\end{array}$ & $\begin{array}{l}\text { Overcome universal } \\
\text { inaccuracies in edge } \\
\text { detection due to shadows }\end{array}$ & Difficult to implement \\
\hline $\begin{array}{l}\text { K. Ghazali et al.(2012) } \\
\text { [21] }\end{array}$ & $\begin{array}{l}\text { Feature- } \\
\text { Based }\end{array}$ & $\begin{array}{l}\text { H-Maxima, Hough } \\
\text { Transform }\end{array}$ & $\begin{array}{l}\text { High efficiency; ability to } \\
\text { detect unexpected lane } \\
\text { changes; good } \\
\text { performance in straight } \\
\text { and curved road conditions }\end{array}$ & $\begin{array}{l}\text { Farthest objects cannot be } \\
\text { determined }\end{array}$ \\
\hline $\begin{array}{l}\text { R. K. Satzoda et al. } \\
\text { (2013)[22] }\end{array}$ & $\begin{array}{l}\text { Model- } \\
\text { Based }\end{array}$ & $\begin{array}{l}\text { IPM, } \quad \text { Steerable } \\
\text { Filter }\end{array}$ & $\begin{array}{l}\text { Effective for embedded } \\
\text { realization; adaptable to } \\
\text { varying } \\
\text { information }\end{array}$ & $\begin{array}{l}\text { Fails in some environmental } \\
\text { conditions }\end{array}$ \\
\hline $\begin{array}{l}\text { S. Fernado et al. (2014) } \\
\text { [76] }\end{array}$ & $\begin{array}{l}\text { Model- } \\
\text { Based }\end{array}$ & $\begin{array}{l}\text { Mahalanobis } \\
\text { distance, Gabor } \\
\text { filter }\end{array}$ & $\begin{array}{l}\text { Uses multiple cues to } \\
\text { achieve robust solution }\end{array}$ & Complex \\
\hline
\end{tabular}

\section{CONCLUSION AND FUTURE SCOPE}

In this paper, a review on lane detection techniques has been done. The feature based techniques includes the same amount of information about the true lane markers as the image intensity gradient field, which are not as sensitive to extraneous edges whereas they posses very high dependency on apparent lane marks and go through from weak marks of lane, occlusions and noise. The model based approach is very less susceptible to weak lane emergence noise and features and is used to improve robustness where edge points are contaminated with noise edges from shadows, cracks, etc whereas complex modeling process involves prior knowledge. Moreover the model that has been constructed for one scenario may not perform well in another scene, which creates the technique less adaptive. Most of them resulted in inaccurate results when input image is infected by fog, noise, night vision images and also most of the research done for straight road images instead of the curved lanes.

Therefore, further improvements are required to improve the accuracy of the lane detection further. In the near future, we will modify the existing Hough transformation so that it can measure both the curved and straight roads. Various steps should be taken to improve the results in different environmental conditions like sunny day, foggy day, rainy day etc.

\section{REFERENCES}

[1] Malaysia Road Safety Department, 2010, "Accidents cost Malaysia RM9.3bil." from http://thestar.com.my/news/

[2] MUFORS; (2011). "Malaysia Sees Increased Road Fatalities."

[3] E.D. Dickmanns and B.D. Mysliwetz, "Recursive 3-D Road and relative Ego-State Recognizition", IEEE Transaction on PAMI, vol 14, no. 2, pp: 199-213, 1992.

[4] A. Broggi and S. Berte, "Vision-based Road Detection in Automotive Systems: a Real-time Expectation-driven Approach", Journal of Artificial Intelligence Research, vol. 3, pp. 325-348, 1995. 
[5] A. Kaske, R. Husson and D.Wolf, "Chi-Square Fitting Of Deformable Templates For Lane Boundary Detection", 1995.

[6] D.J Kang, J.W. Choi and I.S. Kweon, "Finding and Tracking Road Lanes Using Line-snakes", Proceedings of Conference on Intelligent Vehicle, pp. 189-194, 1996.

[7] M. Bertozzi and A. Broggi, "GOLD: A Parallel Realtime Stereo Vision System for Generic Obstacle and Lane Detection", IEEE Transactions of Image Processing, pp:62-81, 1998.

[8] Y. Wang, D. Shen and E.K. Teoh. "Lane Detection Using Catmull-Rom Spline". In Proc. of the IEEE Intelligent Vehicles, 1998.

[9] C. Kreucher and S. Lakshmanan, "LANA: A lane extraction algorithm that uses frequency domain features," IEEE Trans. Robot. Autom., vol. 15, no. 2, pp. 343-350, Apr. 1999.

[10] G. Loy, L. Fletcher, N. Apostoloff and A. Zelinsky. "An adaptive Fusion Architecture for Target Tracking". Proc. 5th Int'l Conf. Automatic Face and Gesture Recognition, IEEE CS Press, pp: 261-266, 2002.

[11] C. Rasmussen, "Combining Laser Range, Color, and Texture Cues for Autonomous Road Following", In Proc. IEEE Inter. Conf. on Robotics \& Automation, Washington, DC, May, 2002.

[12] J.C. McCall, M.M. Trivedi, "Video based lane estimation and tracking for driver assistance: survey, system and evaluation", IEEE Transact. Intelligent Transport. System, pp: 20-37, 2006.

[13] C. Rasmussen, "Texture-based vanishing point voting for road shape estimation", BMVC, 2004.

[14] Y. Wang, E.K. Teoh and D. Shen, "Lane detection and tracking using B-Snake", Image Vision Comput. 22, pp: 269-280, 2004.
[15] J.C. McCall, M.M. Trivedi, "Video based lane estimation and tracking for driver assistance: survey, system and evaluation", IEEE Transact. Intelligent Transport. System, pp: 20-37, 2006.

[16] Z. Kim, "Robust Lane Detection and Tracking in Challenging Scenarios", In IEEE Transactions on Intelligent Transportation Systems, vol. 9, no. 1, pp. 16 26, 2008.

[17] J.M. Alvarez and A. Lopez, "Novel Index for Objective Evaluation of Road Detection Algorithms", Proceedings of the 11th International IEEE Conference on Intelligent Transportation Systems, Beijing, China, pp: 12-15, 2008.

[18] M. Aly, "Real time Detection of Lane Markers in Urban Streets", In IEEE Intelligent Vehicles Symposium, pp. 7 $-12,2008$.

[19] Z. Teng, J.H. Kin and D.J. Kang, "Real-time Lane detection by using multiple cues", In IEEE International Conference on Control Automation and Systems, pp. 2334 - 2337, 2010

[20] S. Zhou, Y. Ziang, J. Xi, J. Gong, G. Xiong and H. Chen, "A novel lane detection based on geometrical model and gabor filter", in IEEE Intelligent Vehicles Symposium, pp. 59-64, 2010.

[21] K. Ghazali, R. Xiao and J. Ma, " Road Lane Detection Using H-Maxima And Improved Hough Transform", Fourth International Conference on Computational Intelligence, Modelling and Simulation, pp: 2166-8531, 2012.

[22] R. K. Satzoda and Mohan M. Trivedi, "Vision-based Lane Analysis: Exploration of Issues and Approaches for Embedded Realization", IEEE Conference on Computer Vision and Pattern Recognition Workshops, 2013.

[23] S. Fernando, L. Udawatta, B. Horan and P. Pathirana, "Real-time Lane Detection on Suburban Streets using Visual Cue Integration", International Journal of Advanced Robotic Systems, 2014. 